\title{
Endocrine regulation of periparturient behaviour in pigs
}

\author{
C. L. Gilbert \\ MAFF Welfare and Behaviour Laboratory, Department of Neurobiology, The Babraham Institute, \\ Babraham, Cambridge CB2 4AT, UK
}

\begin{abstract}
Pigs begin behavioural preparations for birth about $1-2$ days before parturition. Prepartum sows wander to select a suitable site and then construct a maternal nest. The signal that initiates this behavioural cascade probably results from fetal maturation but is unknown. However, endogenous $\mathrm{PGF}_{2 \alpha}$ appears to be involved early on in an endocrine pathway that projects to the brain and can generate most of the prepartum behavioural components. This period of intense activity is followed by a quiescent phase of lying in the nest for some hours before fetal ejection occurs. Feedback from a completed nest or abdominal discomfort may both contribute to the end of nest building. In the postpartum phase, sows have to deal with the apparently conflicting drives of remaining passive to reduce accidental or deliberate damage to piglets, while at the same time responding actively to their needs. In commercial environments, animals frequently fail in this task. Although environmental influences on piglet survival have received much experimental attention, the genetic, social and endocrine drives that control sow behaviour after parturition remain poorly understood and their clarification is a major challenge for the future.

)!
\end{abstract}

\section{Introduction}

Behavioural changes associated with birth consist of much more than the process of fetal expulsion alone. For the purposes of this review the onset of periparturient behaviour is defined as the first observable prepartum behavioural change and the end as the establishment of stable neonatal-maternal relationships with the onset of regular nursing.

Variations in maternal behaviour result from the product of genetic background, individual previous experience and immediate environmental feedback impinging upon innate drives. Although modern domestic sows are many generations removed from their wild boar ancestors, innate periparturient behaviours appear to be similar (Špinka et al., 2000). As the sequence of behaviours seen during birth are not observed at other times and their timing is crucial for reproductive success, it seems likely that signals from mature fetuses or placentae are likely to trigger these behavioural changes. Such signals could be relayed from the uterus to the brain by afferent nerve stimulation via ascending spinal pathways or through the bloodstream and across the blood-brain barrier via areas of 'leakiness' such as the 
circumventricular organs (McKinley et al., 1998) or by specific carrier systems. The initiation of the physiological and endocrine events that lead to parturition in sheep has been traced to fetal pituitary adrenocorticotrophic hormone (ACTH) secretion (for review see Challis and Lye, 1994). However, there is no clear evidence that a similar system operates in pigs (Randall et al., 1990). This is an example of an argument (Naaktgeboren, 1979) that multiparous animals (for example, pigs, rabbits, carnivores and rodents) and usually uniparous animals (for example ungulates) should be considered in two broadly separate categories in most aspects of their periparturient physiology.

With the advent of intensive husbandry systems, the environment in which commercial pigs give birth is frequently very different from that of their wild ancestors. Concern over the extent to which intensification prevents or alters normal behaviour patterns, potentially causing maternal stress, has been the subject of much recent research. However, this review will concentrate on describing parturient behaviours unhindered by potentially impoverished environments, and what is known of their endocrine regulation, in an attempt to place these applied studies in context.

\section{The prepartum period}

\section{Normal behaviour}

Preparatory behaviours for birth in domestic sows with space to roam through different environments and terrain in large semi-natural enclosures have been described in a series of reports (for example, Jensen, 1986; Jensen et al., 1987, 1991, 1993). The first observable changes in behaviour occur about $48 \mathrm{~h}$ before giving birth, when animals become restless before a period of concentrated walking, interpreted as nest-site seeking and selection behaviour. During this time, either as an indirect consequence of increased locomotion or as a result of deliberate action, animals tend to leave the herd home range. They may walk several kilometres and build one or more 'mock nests' before final nest-site selection and construction. The nest is built by first digging a hollow in the ground using the snout and raking movements with the front hooves. A mixture of vegetation is gathered from nearby and arranged within the hollow using the snout and hooves to form a nest with a deep bed. This sequence of behaviours may continue for more than a day, declining 3-7 h before birth of the first piglet. In preparation for this phase, sows characteristically push their bodies into the nest using a lowered, turned head and forelegs before lying recumbent on their sides. Nest building does not normally occur after this time (Petersen et al., 1990), although some repairs and improvements after parturition have been observed (Jensen et al., 1987). Nest quality is an important determinant of the timing of the end of nest building, as sows with access to fewer types of material continued to build, in some cases into the postpartum period (Damm et al., 2000).

Motivation to change behaviour in the prepartum period may initially be the result of 'internal factors' such as endocrine change, with 'external factors' such as environmental feedback becoming increasingly important as nest-building progresses (Jensen et al., 1993).

\section{Endocrine regulation}

Although a great deal is now known about how pig plasma concentrations of substances relevant to parturition vary over time, we are still a long way from understanding how these variations translate, if at all, into the molecular and neuronal events that drive behavioural change. However, plasma concentrations of many reproductive hormones are in a rapid state of change in the prepartum period, when behavioural change occurs (see Fig. 1) and some 


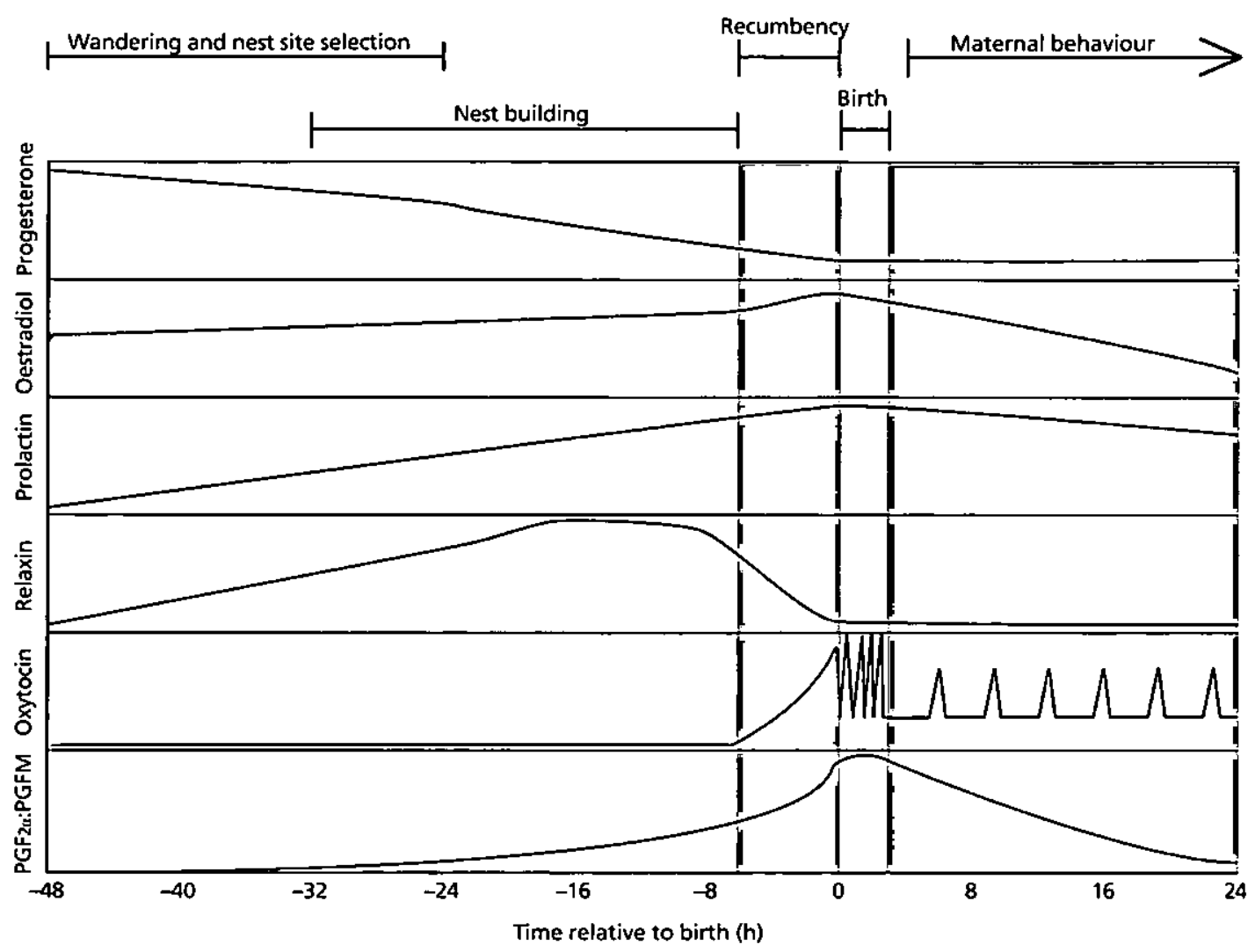

Fig. 1. Trends in plasma concentrations of key hormones about the time of parturition in pigs and their relationship to behavioural change. No scaling of absolute values is given. Sources of data include: Ellendorff et al. (1979); Taverne et al. (1982); Watts et al. (1988); King and Wathes (1989); Whitely et al. (1990); MeunierSalaün et al. (1991); Castrén et al. (1993a,b); Gilbert et al. (1994); and Gilbert (1999).

experiments have been performed in which alteration in plasma hormone content has led to behavioural change. Of these, the main known causal relationship between the endocrine system and nest building is the strong evidence that endogenous $\mathrm{PGF}_{2 \alpha}$ initiates and mediates these behaviours (see Fig. 2).

$P G F_{2 \alpha}$ and nest building behaviour. Peripheral injection of luteolytic doses of $P G F_{2 \alpha}$ to late pregnant sows rapidly induced behaviours very similar to nest building, whereas a synthetic analogue of $\mathrm{PGF}_{2 \alpha}$ cloprostenol, had a minimal behavioural effect (Widowski et al,, 1990). Remarkably, $\mathrm{PGF}_{2 \alpha}$ has also been shown to induce nest building behaviours in postpartum (Blackshaw, 1983), pseudopregnant (Boulton et al., 1997a) and cyclic (Blackshaw, 1983; Burne et al., 2000a) sows. Behavioural elements that have been recorded include increased locomotion and isolation in outdoor enclosures, comparable to prepartum wandering (Gilbert et al., 2000a), snout rooting and front leg pawing at the ground, and carrying and arranging straw (Burne et al., 2000a,b). These induced behaviours appear to be dependent on environment (outdoors, strawed pen or farrowing crate), but are separate from the nest building associated with temperature regulation (Burne et al., 2001). This is an important distinction as thermoregulatory motivators can also generate nest building, particularly in 


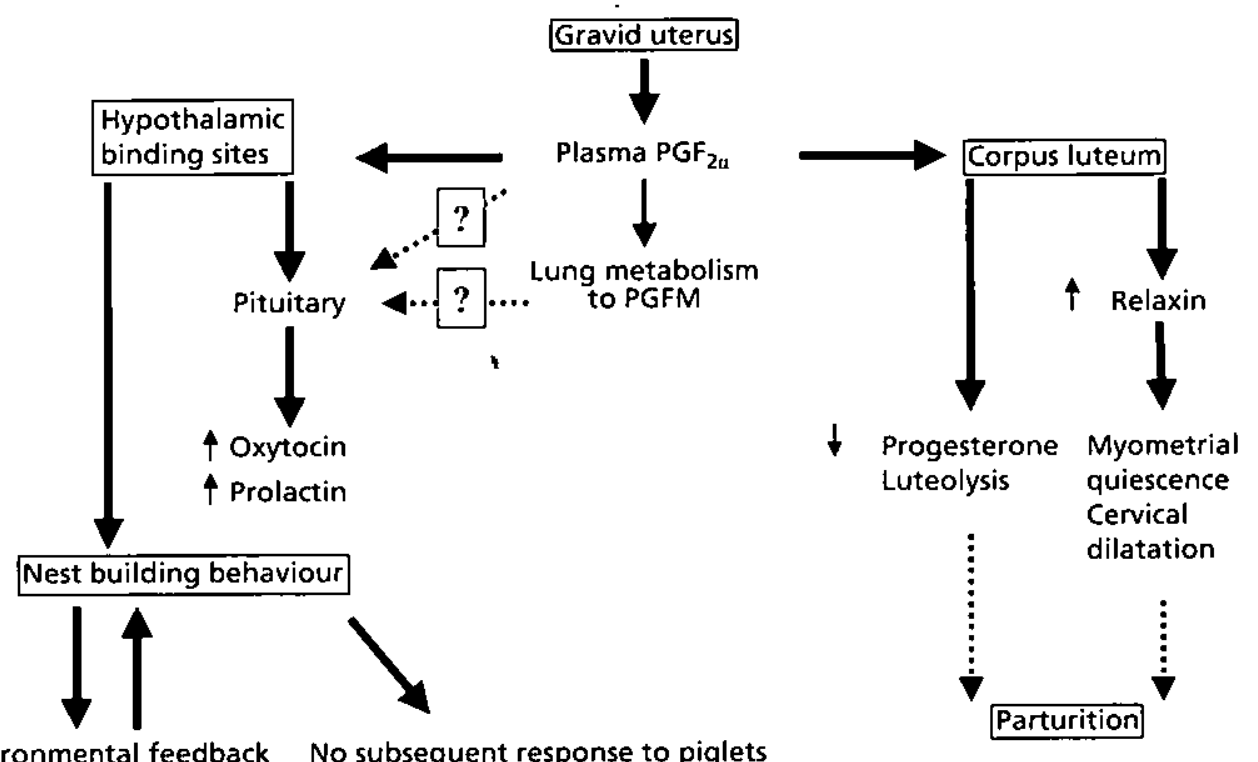

Environmental feedback No subsequent response to piglets

Fig. 2. Schematic representation of proposed regulation of parturient behaviour in pigs by endogenous $\mathrm{PGF}_{2 \alpha}$. Although $\mathrm{PGF}_{2 \alpha}$ is able to bring about all of the changes shown, it remains unclear whether it is the primary endogenous regulator in all cases. PGFM: 13,14 dihydro-15keto-PGF $2 \alpha$.

rodent species (Bhatia et al., 1995). Recently, Burne et al. (2000c) suggested that the development of $\mathrm{PGF}_{2 \alpha}$-induced nest building is dependent upon age and appears at about the time of puberty.

$\mathrm{PGF}_{2 \alpha}$ can be synthesized by the uterine endometrium (Uzumcu et al., 1998) and may be released by the placenta in preparturient animals (Silver et al., 1979), although the stimulation of release is not understood. Studies in other species support the idea that feto-placental synthesis of prostaglandins occurs in late pregnancy (Mitchell et al., 1995). Plasma secretion of $\mathrm{PGF}_{2 \alpha}$ in the prepartum period has been measured (Watts et al., 1988; Whitely et al., 1990)

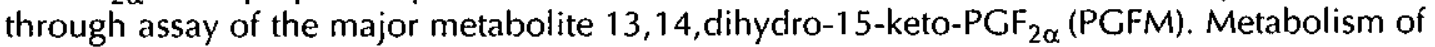
$\mathrm{PGF}_{2 \alpha}$ to PGFM in the lungs of pigs is only $80 \%$ efficient, whereas in a non-nest-building species, sheep, this figure approaches $100 \%$ (Davis et al., 1979). Therefore, it is likely that some peripherally secreted $\mathrm{PGF}_{2 \alpha}$ could access the brains of pigs. However, no study so far has convincingly demonstrated an increase in circulating concentrations of $\mathrm{PGF}_{2 \alpha}$ or PGFM coincident with the nest-building phase. Insufficient sampling frequencies plus the use of a metabolite assay may have contributed to this deficiency. In addition, prostaglandin synthesis in the brain may be occurring that is not measurable by peripheral sampling. However, there is clearly a sharp increase in PGFM immediately before parturition, after nest building has finished and during the behaviourally quiescent, recumbent phase (Fig. 1). This presents the hypothesis with a problem. Behaviours that are readily inducible with exogenous $\mathrm{PGF}_{2 \alpha}$ are not observed at the time when endogenous PGFM concentrations are at their peak. This paradox is a good example of the danger inherent in trying to understand endocrine control of behaviour from the standpoint of plasma concentrations alone, without related data on receptor kinetics and signalling events. Unfortunately, information of this latter type is very scarce for pigs (especially in the central nervous system). However, if the $\mathrm{PCF}_{2 \alpha}$-induced nest-building hypothesis is correct, the continuing increase in plasma prostaglandin 
concentrations during the recumbent phase requires either alterations in the sensitivity of central behavioural receptor systems to $\mathrm{PGF}_{2 \alpha}$ or other systems acting to override the stimulatory effect of $\mathrm{PGF}_{2 \alpha}$ on nest-building. Increasing prepartum peripheral oxytocin concentrations (Gilbert, 1999) correlates with the end of nest building in pigs (Castrén et al., 1993a), together with the associated increase in intensity of uterine concentrations and abdominal discomfort (Naaktgeboren, 1979; Taverne et al., 1979). Whether recumbency and behavioural quiescence are a simple function of a response to abdominal discomfort or specific effects produced directly by an altered endocrine state is unclear, but the former option seems plausible. However, central neuronal activation has been observed after prepartum increases in peripheral oxytocin concentrations (Antonijevic et al., 1995) and central oxytocin is an important mediator of postpartum behaviour in rodents (see below).

Receptors to $\mathrm{PGF}_{2 \alpha}$ are synthesized in pig hypothalamic nuclei (Burne, 2000). Cells in similar areas are activated by peripheral $\mathrm{PGF}_{2 \alpha}$ treatment (Walton et al., 2001). This is a possible site of action for the initiation of prepartum behavioural change. Although it is uncertain which cell type possesses PGF $2 \alpha$ receptors, glial cells express PGF $_{2 \alpha}$ mRNA in rats (Kitanaka et al., 1996) and brain microvessels possess these receptors in pigs (Chemtob et al., 1996). In rats, local $P G F_{2 \alpha}$ infusion altered the firing rate of neurones in the supraoptic nucleus (Setiadji et al., 1998). However, no information is available on $\mathrm{PGF}_{2 \alpha}$ modulation of neuronal activity in pigs and the downstream central mechanisms that result in behavioural changes are unknown.

In addition to altering behaviour, $\mathrm{PGF}_{2 \alpha}$ also generates rapid increases in plasma concentrations of prolactin and oxytocin (Boulton et al., 1997b). Plasma concentrations of progesterone increase acutely, followed by a longer-term decrease associated with luteolysis (Boulton et al., 1997b). It is possible that these induced increases may account for some of the reported correlative data between these hormones and nest building behaviours. For example, the preparturient increase in plasma prolactin concentrations may be responsible for the initiation of nest building, as these events occur at similar times (Castrén et al., 1993a). However, these data do not imply causality and Boulton et al. (1998) showed that profound reduction of peripheral prolactin concentrations with bromocriptine failed to prevent $\mathrm{PGF}_{2 \alpha^{-}}$ induced nest-building behaviours. It is possible that central mechanisms that generate nest building also produce downstream prolactin secretion. Similarly, the duration of straw gathering behaviour has been positively correlated with plasma progesterone concentrations (Castrén et al., 1993a), but neither the sex steroid ratio (Boulton et al., 1997b) nor oestradiol supplementation (Burne et al., 1999) affected $\mathrm{PGF}_{2 \alpha}$-induced nest-building behaviour. However, endocrine control of nest building appears to be species-specific, as both prolactin and variations in the ratio of circulating oestrogen:progesterone affect digging, straw-carrying and hair-pulling (to line a nest) behaviours in late pregnant rabbits (Gonzalez-Mariscal et al., 1996).

Relaxin. The timing of the endogenous prepartum relaxin surge is not fully understood. Some experiments have shown that corpora lutea of pregnancy produce a relaxin surge 112-114 days after mating even in the absence of a gravid uterus (for example see Felder et al., 1988). This raises the intriguing idea of an 'internal clock' in the ovary or central nervous system that measures the duration of gestation independently of uterine signals and initiates endocrine events leading to parturition. Although $\mathrm{PGF}_{2 \alpha}$ stimulates relaxin secretion (Sherwood et al., 1979; King and Wathes, 1989) and prepartum plasma concentrations of relaxin appear to be closely related in time to nest-building behaviour (Fig. 1), relationships between the prepartum relaxin surge and behaviour have not been tested systematically. In 
rodents, relaxin can affect neuronal activity in the hypothalamus through binding to receptors in areas of blood-brain barrier weakness (Heine et al., 1997; McKinley et al., 1998). Summerlee et al. (1998) proposed that in rats a central relaxin system controlling the timing of birth exists discretely from the peripheral system regulating uterine motility and cervical softening, but the only report of centrally applied relaxin affecting behaviour relates to drinking (Summerlee and Robertson, 1995).

In addition to central effects, relaxin has important functions in the late pregnant uterus, preventing inappropriate early myometrial contractions and inducing cervical softening (Bagnall et al., 1993). The co-ordination of cervical softening, prevention of inappropriate early uterine contraction and prepartum behaviour by a single system is an attractive hypothesis, as the events clearly need to be co-ordinated in time. It is possible that relaxin may act to counteract the uterotonic influences of $\mathrm{PGF}_{2 \alpha}$ during nest building, with the end of the relaxin surge allowing myometrial activity to increase, which would in turn adjust behaviour away from nest building towards recumbency and expulsive effort.

\section{Fetal delivery}

Notwithstanding effects on nest-building behaviour, prostaglandins also appear to be required for parturition to occur (Nara and First, 1981). This effect is probably due to a peripheral action of $\mathrm{PGF}_{2 \alpha}$ on the corpora lutea of pregnancy to remove luteal support to the pregnancy, as has been shown clearly in $\mathrm{PGF}_{2 \alpha}$ receptor knockout mice (Sugimoto et al., 1997). Indeed, $\mathrm{PGF}_{2 \alpha}$ analogues are frequently used commercially to induce parturition and various combinations of $\mathrm{PGF}_{2 \alpha}$ and oxytocin have been tested experimentally (for review see Gilbert, 1999).

Piglets are nearly always born with sows lying in lateral recumbency and fetal expulsion through the birth canal is accompanied by visible and powerful contractions of the external abdominal musculature (Randall, 1972). The rate at which piglets are expelled is variable. Mean duration of second stage labour has been reported as $2.5 \mathrm{~h}$ with a range of $0.5-10.5 \mathrm{~h}$, and mean piglet interval as $16.0 \mathrm{~min}$ with a range (per litter) of $4.2-48.4 \mathrm{~min}$ with animals in a variety of commercial environments (Randall, 1972). Data sets from semi-natural environments are much smaller, but report somewhat slower (Petersen et al., 1990) or similar (Jensen, 1986) birth rates. Although nest building is discontinued during parturition, some postural changes occur. Typically, sows stand, inspect piglets and lie down again (Petersen et al., 1990). This behaviour has been studied more systematically in more intensive conditions (Edwards and Furniss, 1988) and appears to be observed more frequently after birth of the first piglet compared with later littermates. Similarly, Jarvis et al. (1999) showed that maternal responsiveness to piglets was high at the onset of farrowing, decreased over the following $4 \mathrm{~h}$ and was restored by the following day.

\section{Endocrine regulation}

The physiology underlying the initiation of powerful uterine contractions at birth has been described elsewhere (for example see Ellendorff et al., 1979; Taverne et al., 1982; Silver et al., 1983). The powerful and visible contractions of the external abdominal muscles that accompany delivery have been described as the 'fetal ejection reflex' in rats, which requires intact pelvic nerves and may be initiated by cervical dilatation (Higuchi et al., 1987). Once the cervix is open, fetal expulsion is achieved by a combination of uterine smooth muscle and abdominal striated muscle contractions. Much of the increase in uterine smooth muscle activity may be attributable to an increase in circulating oxytocin secretion, which begins to 
increase above baseline values at about $7 \mathrm{~h}$ before birth (Gilbert, 1999). However, oxytocin gene knockout mice were able to give birth normally (Nishimori et al., 1996), indicating that other uterotonic agents (Challis and Lye, 1994) are able to compensate for a lack of oxytocin, and implying considerable flexibility and redundancy in the system (Russell and Leng, 1998).

Oxytocin secretion during parturition is under inhibitory regulation by central endogenous opioids (Leng and Russell, 1989), which are responsible for inhibiting parturition in stressful circumstances (Lawrence et al., 1992). However, as parturition is likely to be inherently both stressful and painful, opioid systems may also be involved normally in regulating oxytocin secretion to time parturition (Gilbert et al., 2000b), help space births (larvis et al., 2000) and, through separate spinal systems, attenuate pain perception (Jarvis et al., 1997).

Cervical dilatation and maternal behaviour. in sheep, recognition of individual lambs and selective bonding occur rapidly after birth and are triggered by mechanical cues from the fetus passing down the birth canal modulating hypothalamic relays, involving centrally released oxytocin with progesterone and oestrogen priming (Kendrick and Keverne, 1991). In pigs, individual recognition of piglets by sows is not observed reliably at day 1 after parturition, but develops by day 7 after parturition (Horrell and Hodgson, 1992; Maletínská et al., 2000). Although vagino-cervical dilatation at birth increases peripheral oxytocin secretion in pigs (Cilbert et al., 1997), there is no evidence that this process contributes to maternal behaviour.

Oxytocin secretion and nursing behaviour. During parturition, oxytocin secretion is increased above pre-term values with pulsatile release superimposed (Castrén et al., 1993b): additional pulses associated with fetal ejection are measurable as increases in intra-mammary pressure (Gilbert et al., 1994). This may aid the release of colostrum, which can be expressed continually during birth. Newborn piglets are highly precocious and often vocal. Having cleared the fetal membranes from around their heads, piglets normally rise rapidly (within $2 \mathrm{~min}$ of birth) and begin to nuzzle their dam, seeking a nipple (Randall, 1972). The discrete milk ejection reflexes characterized by maternal behavioural (Algers et al., 1990; Jensen et al., 1991), endocrine (Ellendorff et al., 1982) and neuronal (Jiang and Wakerley, 1995) changes that develop as lactation progresses are not behaviourally apparent immediately after parturition (Herskin et al., 1999). This apparently minimal maternal constraint to suckling may help neonates, as teats may initially be hard to find or regain once lost, due to sibling competition, so a continuous letdown maximizes the chance of an early meal (for review see Fraser et al., 1995).

\section{The postpartum period}

\section{Normal maternal behaviour}

Normal pig maternal behaviour is rather different in the $24 \mathrm{~h}$ after birth compared with later periods during lactation (lensen et al., 1991) and is characterized by high nest occupancy (Stangel and Jensen, 1991). In the immediate postpartum period, removal of placental membranes and licking of individual piglets by sows does not normally occur. Furthermore, in contrast to species such as the rat (Bridges, 1990), carrying of offspring in the mouth and retrieval to the nest is not observed. Duration of maternal lateral lying in the first day after parturition is high (Meunier-Salaün et al., 1991; Cronin and Smith, 1992). Newborn piglets may be weak (Fraser, 1990) and are often located at or near the udder on the day after birth 
(Cronin and Smith, 1992), such that relatively minor postural changes by the mother (such as rolling over) can endanger piglets (Weary et al., 1996), with a greater likelihood of accidental damage or death to piglets than later on in lactation (Marchant et al., 2001). Newborn piglets are relatively small ( $\leqslant 0.5 \%$ of maternal weight) but highly precocious and will fight for access to teats. They normally establish a stable teat order and dominance hierarchy within a few days, thereby minimizing further antagonistic interactions (Fraser et al., 1995).

Throughout this period of maternal behaviour there is a conflict between the sow investing in her own wellbeing and that of her piglets. The inability of some sows to adapt sufficiently to perform adequately the tasks associated with maternal care is shown by the existence of 'death-prone litters' (Fraser, 1990; Fraser et al., 1995), in which too many deaths occur for the overall frequency of mortality to conform to a Poisson distribution (Fraser, 1990). Large litter size, maternal disease or low milk yield may account for some death-prone litters, but many are the result of poor maternal care. In sows with an equivalent metabolic status and similar husbandry systems (such as housing and temperature regulation), there is still large variation in maternal behaviour (van der Steen et al., 1988; Fraser, 1990), which must be caused by either genetic predisposition or the consequences of an individual's previous experience. An example of selective breeding producing effects on maternal behaviour has recently been published (McPhee et al., 2001). The effects of earlier maternal experience (Jarvis et al., 2001) and other physical and social experiences also appear to influence the subsequent maternal behaviour of pigs (for example, Varley and Stedman, 1993; Beattie et al., 1995). For example, sows that are dominant during pregnancy are more active immediately before farrowing and allow their piglets to suckle more freely than do lower ranking sows. In contrast, low ranking sows are more restless in the early phase after farrowing and can show stereotyped and redirected behaviour patterns (Csemmely and Nicosia, 1991).

Underprivileged piglets may eventually die as a result of overlying, hypothermia or intercurrent disease. However, excessive maternal activity for whatever reason is likely to contribute to accidental damage to offspring. Indeed, Jarvis et al. (1999) suggested that optimum maternal behaviour in the first day after parturition is characterized by passivity, unresponsiveness to piglets and lateral lying, allowing both a reduced risk of crushing and maximum access to teats. However, it is also clear that later in lactation, as maternal-piglet relationships develop, responsiveness to piglet distress calls plays an important part in reducing crush injuries (Wechsler and Hegglin, 1997).

\section{Aggressive infanticide}

In addition to accidental injury, deliberate maternal aggression of sows towards offspring has been described in large surveys of commercial piggeries with incidences of $8 \%$ (Knap and Merks, 1987) and 7-12\% (van der Steen et al., 1988) of sows giving birth, a significant heritability and prevalence in primparous sows (gilts). The behaviour is characterized by sows killing some or all of their offspring by biting them to death. Most piglets are killed within day 1 after parturition. Although animals that are predisposed to aggressive infanticide do not show obvious warning signs before farrowing, recent evidence suggests that variations in posture in the day before birth might be useful as behavioural predictors (Appleyard et al., 2000), and animals that show maternal aggression appear to be less aggressive to pen-mate sows during pregnancy (McLean et al., 1998).

Whether this phenotype is part of a continuum of poor maternal behaviour related to a failure in maternal passivity (Jarvis et al., 1999) or an entirely separate event is unknown. Carcasses may be consumed but are often discarded, so hunger is unlikely to be the cause. 
Whether this aggressive behaviour is limited to a sow's own offspring, or would be directed to any piglets or other foreign objects, has not been tested. This would be useful information as it might show whether the sow's aggression is a response to a general increase in reactivity or fearfulness or is a specific rejection of her own piglets.

\section{Endocrine regulation}

Most studies on maternal behaviour support regulation by neuro-endocrine systems that originate in and are co-ordinated by hypothalamic nuclei, particularly the medial.pre-optic area, paraventricular nucleus, supraoptic nucleus and associated projections. These brain areas are responsive to the changes in ovarian and uterine hormone secretion that occur in late pregnancy. Much of this evidence is derived from studies in laboratory rodents (for example see Bridges et al., 1999) but some studies have also been performed in pigs.

Sex steroids. In rats, increased circulating concentrations of oestrogens with progesterone promote maternal behaviour in virgin rats exposed to newborn pups (for review see Bridges, 1990), whereas in mice, marginal progesterone concentrations during pregnancy increased maternal rejection of pups (Wang et al., 1995). Although similar studies have not been performed in pigs, sedative treatment of sows for maternal aggression was associated with high prepartum oestrogen:progesterone ratios and high postpartum plasma oestradiol concentrations (McLean et al., 1998). Both oestrogen receptor $\alpha$ and $\beta$ are found in the brain in rodents, with high concentrations of both subtypes again located in the hypothalamus (Laflamme et al., 1998). Progesterone receptors are found in rat hypothalamus, preoptic area, hippocampus and frontal cortex, with hypothalamic expression of the B-isoform being sensitive to reproductive status (GuerraAraiza et al., 2000). Both genomic and non-genomic effects of progesterone on central neurotransmitters relevant to reproductive behaviour have been reported (Schumacher et al., 1999). Many neurones that contain either oestrogen or progesterone receptors are neuroendocrine in type, as they have been shown to project to the median eminence (Goldsmith et al., 1997).

Oxytocin. Central oxytocin appears to be important in mediating maternal behaviour, although this has not been proven in pigs. For example, administration of oxytocin into the cerebrospinal fluid of mice reduced aggressive infanticide (McCarthy, 1990) and similar treatment with an oxytocin antagonist inhibited postpartum maternal behaviour in rats (van Leengoed et al., 1987). However, oxytocin gene knockout mice did not show any gross deficits in maternal care apart from an inability to nurse, which is probably due to peripheral effects (Nishimori et al., 1996). Oxytocin injection into the medial pre-optic area or paraventricular nucleus reduced maternal rejection of lambs in sheep (Kendrick et al., 1992). In our laboratory, we have evidence that gilts displaying aggressive behaviour to offspring also had lowered peripheral oxytocin concentrations at birth (C. L. Gilbert, T. H. J. Burne, J. A. Goode and P. J. E. Murfitt, unpublished; Fig. 3). This could be a clue to causality but it could also simply be that aggressive sows receive less tactile stimulation of the nipples (Algers et al., 1990). Furthermore, endogenous opioid systems may mediate passivity in parturient sows (Jarvis et al., 1999) but generally also reduce oxytocin secretion.

$P G F_{2 \alpha}$. Despite its effects on prepartum behaviour, peripheral $P G F_{2 \alpha}$ could not be shown to influence responses of female pigs to newborn piglets (Gilbert et al., 2001). Although only a single study of this kind has been performed, this permits the hypothesis that pre- and postpartum mechanisms regulating behaviour may be separate. 


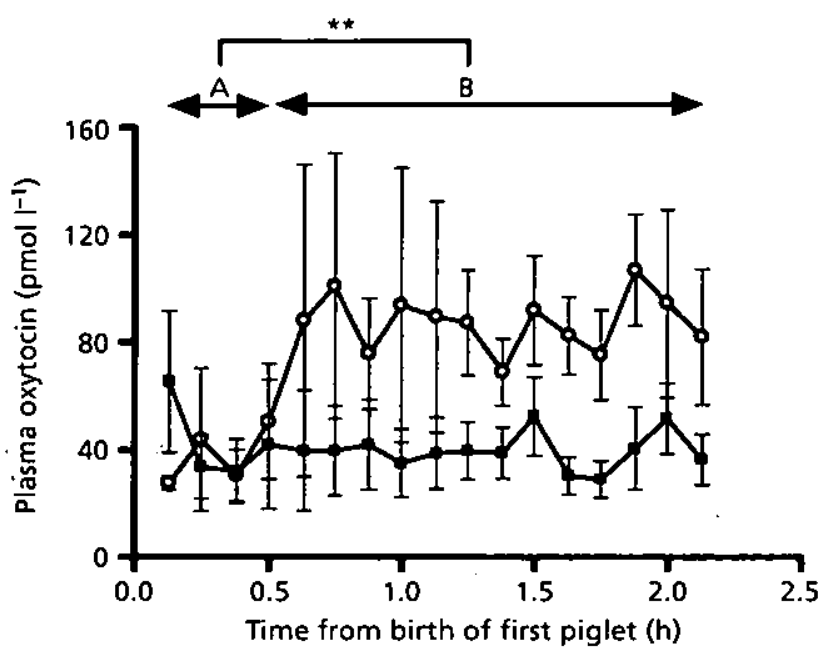

Fig. 3. Plasma oxytocin concentrations in pigs during parturition. Animals were classified as aggressive $(0, n=4)$ if they attacked or bit any of their piglets during the period shown. Non-aggressive controls $(0, n=4)$ gave birth under the same conditions. Data are derived from a large experiment (C. L. Gilbert, T. H. J. Burne, J. A. Goode and P. J. E. Murfitt, unpublished) in which maternal aggression occurred sporadically. All animals had previously received $10 \mathrm{mg}$ $\mathrm{PGF}_{2 \alpha}$ to induce parturition. Mean values in period $A$ were subtracted post-hoc from those in period $B$ for each animal separately and compared using a one-way ANOVA. ${ }^{* *}$ Indicates significant difference $(P<0.01)(F=14.5, \mathrm{df}=7)$.

Prolactin. Studies in rodents have established a clear role for prolactin receptors in maternal behaviour (Lucas et al., 1998). Central receptors (particularly the long form) are located predominantly in the choroid plexus and are also distributed widely in hypothalamic nuclei (Pi and Grattan, 1998).

\section{Conclusion}

The active maternal prepartum phase followed by a relatively passive postpartum response to active (but not individually recognized) offspring are features of pig behaviour that, when combined, differ from other domestic or laboratory species and represent a distinctive model for the study of maternal behaviour. Endocrine regulation of prepartum behaviour is becoming more clearly understood, although central relays turning peripheral cues into coordinated behavioural output are unknown. Postpartum maternal behaviour has been well described, but what we know of its endocrine control amounts to no more than a few disconnected snippets. Similarities in some aspects of behaviour with other multiparous species allow comparisons of the mechanisms of regulation to be made when information is unavailable in pigs, but these must be treated with caution. An inability to resolve the apparently opposite behavioural requirements of postpartum sows to be generally passive yet responsive to piglet distress may be partly responsible for sows that go on to show inadequate maternal behaviour. 
This review has not touched on the large body of work that has examined environmental influences on sow behaviour and endocrinology at birth from the perspective of animal welfare. A thorough understanding of basic mechanisms, once established, will help to place these studies in context and improve the well-being of parturient pigs and their offspring.

The author is grateful to J. Bicknell and T. H. J. Burne for constructive comments on the manuscript. Experiments performed in this laboratory were funded by the UK Ministry for Agriculture, Fisheries and Food (commissions AWO117 and AWO118).

\section{References}

Algers B, Rojanasthian S and Uvnäs-Moberg K (1990) The relationship between teat stimulation, oxytocin release and grunting rate in the sow during nursing Applied Animal Behaviour Science 26 267-276

Antonijevic IA, Leng G, Luckman SM, Douglas A), Bicknell RJ and Russell JA (1995) Induction of uterine activity with oxytocin in late pregnant rats replicates the expression of c-fos in neuroendocrine and brain stem neurons as seen during parturition Endocrinology 136 154-163

Appleyard SJ, Hall AD and Lawrence AB (2000) Prefarrowing behaviour distinguishes piglet-savaging gilts from non-savaging gilts. Proceedings of the $34^{\text {th }}$ International Congress of the ISAE pp 62 Eds A Ramos, LCP Machado Filho and MJ Hotzel

Bagnall CA, Zhang Q, Downey B and Ainsworth L. (1993) Sources and biological actions of relaxin in pigs fournal of Reproduction and Fertitity Supplement 48 127-138

Beattie VE, Walker N and Sneddon IA (1995) Effect of rearing environment and change of environment on the behavior oí gilts Applied Animal Behaviour Science 46 57-65

Bhatia Al, Schneider JE and Wade GN (1995) Thermoregulatory and maternal nestbuilding in Syrian hamsters: interaction of ovarian steroids and energy demand Physiology and Behavior 58 141-146

Blackshaw JK (1983) Prostaglandin $F_{2 a}$ induced nest building behavior in the non-pregnant sow, and some welfare considerations International fournal for the Study of Animal Problems 4 299-304

Boulton MI, Wickens A, Brown D, Goode JA and Gilbert CL (1997a) Prostaglandin F2alpha-induced nestbuilding in pseudopregnant pigs. I. Effects of environment on behaviour and cortisol secretion Physiology and Behavior 62 1071-1078

Boulton MI, Wickens A, Brown D, Goode JA and Gilbert CL (1997b) Prostaglandin F2alpha-induced nestbuilding in pseudopregnant pigs. II. Space restriction stress does not iniluence secretion of oxytocin, prolactin, oestradiol or progesterone Physiology and Behavior 62 1079-1085

Boulton MI, Wickens A, Goode JA and Gilbert CL (1998) Pralactin and induced nest-building behaviour in pscudopregnant gilts treated with bromocriptine Journal of Neuroendocrinology 10 601-609

Bridges RS (1990) Endocrine regulation of parental behaviour in rodents. In Mammalian Parenting Biochemical, Neurobiological, and Behavioural Determinants pp 93-117 Eds NA Krasnegor and RS Bridges. Oxford University Press, Oxford
Bridges RS, Mann PE and Coppeta IS (1999) Hypothalamic involvement in the regulation of maternal behaviour in the rat: inhibitory roles for the ventromedial hypothalamus and the dorsal/anterior hypothalamic areas Journal of Neuroendocrinology 11 259-266

Burne THJ, Murfitt PJE, Goode JA, Boulton MI and Gilbert CL. (1999) Effects of oestrogen supplementation and ace restriction on $\mathrm{PGF}_{2 \alpha}$-induced nest-building in pseudopregnant gilts Animal Production Science 55 255-267

Burne THJ (2000) Expression of PGF-2-alpha receptor mRNA in the female pig brain European Journal of Neuroscience 12407

Burne THJ, Murfitt PJE and Gilbert CL (2000a) Behavioural responses to intramuscular injections of prostaglandin $F_{2 \alpha}$ in female pigs Pharmacology, Biochemistry and Behavior $66789-796$

Burne THJ, Murfitt PJE and Gilbert CL (2000b) Deprivation of straw bedding alters $\mathrm{PCF}_{2 \alpha}$-induced nesting behaviour in female pigs Applied Animal Behaviour Science 69 215-225

Burne THJ, Murfitt PJE and Gilbert CL (2000c) Effects of ovariohysterectomy and age on $\mathrm{PCF}_{2 a}$ induced nest building in female pigs Vith international Conference on Hormones, Brain and Behaviour (Madrid, Spain) Trabajos del Instituto Cajal Tomo 77 350-352

Burne THJ, Murfitt PJE and Gilbert CL (2001) The effect of temperature on prostaglandin $F_{2 \alpha}$-induced nesting behaviour in pigs (Sus scrofa). Applied Animal Behaviour Science 71 293-304

Castrén H, Algers B, de Passillé A-M, Rushen J and UvnäsMoberg K (1993a) Parturient variation in progesterone, prolactin, oxytocin and somatostatin in relation to nest building in soivs Applied Animal Behaviour Science 38 91-102

Castrén $H$, Algers B, de Passillé A-M, Rushen J and UvnäsMoberg K (1993b) Early milk ejection, prolonged parturition and periparturient oxytocin release in the pig Animal Production 57 465-471

Challis JRG and Lye 5J (1994) Parturition. In The Physiology of Reproduction pp 985 Eds E Knobil and ID Neill. Raven Press L.td, New York

Chemtob S, Li D.Y, Abran D, Peri KG and Varma DR (1996) Regulation of cerebrovascular prostaglandin $E_{2}$ $\left(\mathrm{PGE}_{2}\right)$ and $P \mathrm{PE}_{2 \alpha}$ receptors and their functions during development Seminars in Perinatology 20 164-172

Cronin GM and Smith IA (1992) Suckling behaviour of sows in farrowing crates and straw-bedded pens Applied Animal Behaviour Science 33 175-189 
Csemmely D and Nicosia E (1991) Maternal behavior in sows of different social rank fournal of Endocrinology 9 83-93

Damm BI, Vestergaard KS, Schroder-Petersen and Ladewig J (2000) The effects of branches on prepartum nest building in gilts with access to straw Applied Animal Behaviour Science 69 113-124

Davis AJ, Fleet IR, Harrison FA and Maule Walker FM (1979) Pulmonary metabolism of prostaglandin $F_{2 \alpha}$ in the conscious non-pregnant ewe and sow fournal of Physiology 301 86P

Edwards SA and Furniss SJ (1988) The effects of straw in crated farrowing systems on peripartal behaviour of sows and piglets British Veterinary journa/ 144 139-147

Ellendorff $F$, Taverne $M$, Elsaesser $F$, Forsling ML, Parvizzi N, Naaktgeboron C and Smidt D (1979) Endocrinology of parturition in the pig Animal Reproduction Science 2 323-334

Ellendorff F, forsling ML and Poulain DA (1982) The milk ejection reflex in the pig Journal of Physiology 333 577-594

Felder fl, Klindt J, Bolt DJ and Anderson LL (1988) Relaxin and progesterone secretion as affected by luteinizing hormone and prolactin after hysterectomy in the pig Endocrinology 122 1751-1760

Fraser $D$ (1990) Behavioural perspectives on piglet survival Journal of Reproduction and Fertility Supplement 40 355-370

Fraser D, Phillips PA, Thompson BK, Pajor EA, Weary DM and Braithwaite LA (1995) Behavioural aspects of piglet survival and growth. In The Neonatal Pig Development and Survival pp 287-312 Ed. MA Varley. CAB International, Wallingíord

Gilbert CL (1999) Oxytocin secretion and management of parturition in the pig Reproduction of Domestic Animals 34 193-200

Gilbert CL, Goode JA and MCGrath TJ (1994) Pulsatile secretion of oxytocin during parturition in the pig: temporal relationship with fetal expulsion journal of Physiology 475 129-137

Gilbert CL, Boulton MI, Forsling ML, Goode JA and McGrath T) (1997) Restricting maternal space during parturition in the pig: effects on oxytocin, vasopressin, and cortisol secretion following vagino-cervical stimulation and administration of naloxone Animal Reproduction Science 46 245-259

Gilbert CL, Murfitt PJE, Boulton MI, Pain I and Burne TH\} (2000a) Effects of prostaglandin $F_{2 \alpha}$ treatment on the behavior of pseudopregnant pigs in an extensive environment Hormones and Behavior 37 229-239

Gilbert CL, Boulton MI, Goode IA and McGrath T) (2000b) The timing of parturition in the pig is altered by intravenous naloxone Theriogenology 53 905-923

Gilbert CL, Murfitt PJE and Burne THJ (2001) Effects of prostaglandin $F_{2 \alpha}$ treatment of pseudopregnant pigs on nest building behavior and subsequent interactions with newborn piglets Hormones and Behavior 39 206-215

Goldsmith PC, Boggan JE and Thind KK (1997) Estrogen and progesterone receptor expression in neuroendocrine and related neurons of the pubertal female monkey hypothalamus Neuroendocrinology 65 325-334
Gonzalez-Mariscal G, Melo Al, Jiménez $\mathbf{P}$, Beyer $\mathbf{C}$ and Rosenblatt IS (1996) Estradiol, progesterone, and prolactin regulate maternal nest-building in rabbits Journal of Neurochemistry 8 901-907

GuerraAraiza C, Cerbon MA, Morimoto $S$ and CamachoArroyo I (2000) Progesterone receptor isolorms expression pattern in the rat brain during the estrous cycle Life Sciences 66 1743-1752

Heine PA, Di S, Ross LR, Anderson L.L and Jacobson CD (1997) Relaxin-induced expression of Fos in the forebrain of the late pregnant rat Reproductive Neuroendocrinology 66 38-46

Herskin MS, Jensen KH and Thodberg K (1999) Influence of environmental stimuli on nursing and suckling behaviour in domestic sows and piglets Animal Science $6827-34$

Higuchi T, Uchide K, Honda K and Negoro H (1987) Pelvic neurectomy abolishes the fetus-expulsion reflex and induces dystocia in the rat Experimental Neurology 96 $443-455$

Horrell I and Hodgson I (1992) The bases of sow-piglet identification. 1. The identification by sows of their own piglets and the presence of intruders Applied Animal Behaviour Science 33 319-327

Jarvis S, McLean KA, Chirnside J, Deans LA, Calvert SK, Molony $V$ and Lawrence AB (1997) Opioid-mediated changes in nociceptive threshold during pregnancy and parturition in the sow Pain 72 153-159

Jarvis S, McLean KA, Calvert SK, Deans LA, Chirnside J and Lawrence AB (1999) The responsiveness of sows to their piglets in relation to the length of parturition and the involvement of endogenous opioids Applied Animal Behaviour Science 63 195-207

Jarvis S, Lawrence AB, McLean KA, Chirnside J, Deans LA, Calvert SK, Gilbert CL, Goode JA and Forsling $\mathrm{ML}$ (2000) The effect of opioid antagonism and environmental restriction on plasma oxytocin and vasopressin concentrations in parturient gilts fournal of Endocrinology $16639-44$

Jarvis S, Van der Vegt BJ, Lawrence AB, McLean KA, Deans LA, Chirnside I and Calvert SK (2001) The effect of parity and environmental restriction on behavioural and physiological responses of pre-parturient pigs Applied Animal Behaviour Science 71 203-216

Jensen P (1986) Observations on the maternal behaviour of free-ranging domestic pigs Applied Animal Behaviour Science 16 131-142

Jensen P, Florén K and Hobroh B (1987) Peri-parturient changes in behaviour in free-ranging domestic pigs Applied Animal Behaviour Science 17 69-76

Jensen P, Stangel G and Algers B (1991) Nursing and suckling behaviour of semi-naturally kept pigs during the first 10 days postpartum Applied Animal Behaviour Science 31 195-209

Jensen P, Vestergaard K and Algers B (1993) Nestbuilding in free-ranging domestic sows Applied Animal Behaviour Science 38 245-255

Jiang QB and Wakerley JB (1995) Analysis of bursting responses of oxytocin neurons in the rat in late pregnancy, lactation and aíter weaning fournal of Physiology 486 237-248 
Kendrick KM and Keverne EB (1991) Importance of progesterone and estrogen priming for the induction of maternal behavior by vaginocervical stimulation in sheep: effects of maternal experience Physiology and Behavior 49 745-750

Kendrick KM, Keverne EB, Hinton MR and Goode JA (1992) Oxytocin, amino acid and monoamine release in the region of the medial preoptic area and bed nucleus of the stria terminalis of the sheep during parturition and suckling Brain Research 569 199-209

King GJ and Wathes DC (1989) Relaxin, progesterone and estrogen profiles in sow plasma during natural and induced parturitions Animal Reproduction Science 20 213-220

Kitanaka J, Hashimoto H, Gotoh $M$ et al. (1996) Expression partern of messenger RNAs for prostanoid receptors in glial cell cultures Brain Research 707 282-287

Knap PW and Merks JWM (1987) A note on the genetics of aggressiveness of primiparous sows towards their piglets Livestock Production Science 17 161-167

Laflamme N, Nappi RE, Drolet G, Labrie C and Rivest S (1998) Expression and neuropeptidergic characterization of estrogen receptors (ER alpha and ER beta) throughout the rat brain: anatomical evidence of distinct roles of each subtype fournal of Neurobiology 36 357-378

Lawrence AB, Petherick IC, McLean K, Gilbert CL, Chapman C and Russell J (1992) Naloxone prevents interruption of parturition and increases plasma oxytocin following environmental disturbance in parturient sows Physiology and Behavior 52 917-923

Leng G and Russell IA (1989) Opioids, oxytocin and parturition. In Brain Opioid Systems in Reproduction pp 231-256 Eds RG Dyer and RJ Bicknell. Oxford University Press, Oxford

Lucas BK, Ormandy Cl, Binart N, Bridges RS and Kelly PA (1998) Null mutation of the prolactin receptor gene produces a defect in maternal behavior Endocrinology $1394102-4107$

McCarthy MM (1990) Oxytocin inhibits infanticide in female house mice (Mus domesticus). Hormones and Behavior 24 365-375

McKinley MJ, Allen AM, Burns P, Colvill LM and Oldfield BJ (1998) Interaction of circulating hormones with the brain: the roles of the subfornical organ and the organum vasculosum of the Lamina terminalis Clinical and Experimental Pharmacology and Physiology 28 S61-S67

McLean KA, Lawrence AB, Petherick JC, Deans $L$, Chirnside J, Vaughan A, Nielsen BL and Webb R (1998) Investigation of the relationship between farrowing environment, sex steroid concentrations and maternal aggression in gilts Animal Reproduction Science $\mathbf{5 0}$ 95-109

McPhee CP, Kerr JC and Cameron ND (2001) Peri-partum posture and behaviour of gilts and the location of their piglets in lines selected for components of efficient lean growth Applied Anima/ Behaviour Science 71 1-12

Maletinská J, Špinka M, Vichová I, Stehulová I, Panamá J and Šimunek J (2000) Sow-piglets recognilion in early postpartum period. Proceedings of the $34^{\text {th }}$ International Congress of the ISAE pp 161 Eds A Ramos, L.CP Machado Filho and MJ Hotzel
Marchant IN, Broom DM and Corning S (2001) The influence of sow behaviour on piglet mortality due to crushing in an open farrowing system Animal Science 72 19-28

Meunier-Salaün MC, Gort F, Prunier $A$ and Schouten WPG (1991) Behavioural patterns and progesterone, cortisol and prolactin levels around parturition in European (Large-White) and Chincse (Meishan) sows Applied Animal Behaviour Science 31 43-59

Mitchell MD, Romero RJ, Edwin SS and Trantman MS (1995) Prostaglandins and parturition Reproduction, Fertility and Development 7 623-632

Naaktgeboren C (1979) Behavioural aspects of parturition Animal Reproduction Science 2 155-166

Nara BS and First NL (1981) Effect of indomethacin and prostaglandin $F_{2 \alpha}$ on parturition in swine fournal of Animal Science 52 1360-1369

Nishimori K, Young L), Guo Q, Wang Z, Insel TR and Matzuk MM (1996) Oxytocin is required for nursing but is not essential for parturition or reproductive behaviour Proceedings National Academy of Sciences USA 93 11 699-11704

Petersen V, Recén B and Vestergaard K (1990) Behaviour of sows and piglets during farrowing under free-range conditions Applied Animal Behaviour Science 26 169-179

Pi XJ and Grattan DR (1998) Distribution of prolactin receptor immunoreactivity in the brain of estrogentreated, ovariectomized rats lournal of Comparative Neurology $394462-474$

Randall CCB (1972) Observations on parturition in the sow. II. Factors influencing stillbirth and perinatal mortality Veterinary Record 90 183-186

Randall GCB, Kendall JZ, Tsang BK and Taverne MAM (1990) Endocrine changes following infusion of fetal pigs with corticotropin in litters of reduced numbers Animal Reproduction Science 23 109-122

Russell JA and Leng G (1998) Sex, parturition and motherhood without oxytocin? Journal of Endocrinology $157343-359$

Schumacher $M$, Coirini H, Robert F, Cuennoun R and EIEtr $M$ (1999) Genomic and membrane actions of progesterone: implications for reproductive physiology and behavior Behavioral Brain Research 105 37-52

Setiadji VS, Shibuya I, Kabashima N, Ibrahim N, Harayama $N$, Ueta $Y$ and Yamashita $H$ (1998) Actions of prostaglandin $E_{2}$ on rat supraoptic neurones fournal of Neuroendocrinology 10927-936

Sherwood OD, Nara BS, Crnekovic VE and First NL (1979) Relaxin concentrations in pig plasma after the administration of indomethacin and prostaglandin $F_{2 \alpha}$ during late pregnancy Endocrinology 104 1716-1721

Silver M, Barnes RJ, Comline RS, Fowden AL, Clover $L$ and Mitchell MD (1979) Prostaglandins in the foetal pig and prepartum endocrine changes in mother and foetus Animal Reproduction Science 2 305-322

Silver M, Comline RS and Fowden AL (1983) Fetal and maternal endocrine changes during the induction of parturition with the PGF analogue, cloprostenol, in chronically catheterized sows and fetuses Journal of Developmental Physiology 5 307-321 
Špinka $M$, Illmann $G$, de Jonge $F$, Andersson $M$, Schuurman T and Jensen P (2000) Dimensions of maternal behaviour characteristics in domestic and wild $\times$ domestic crossbred sows Applied Animal Behaviour Science 70 99-114

Stangel $G$ and Jensen $P$ (1991) Behaviour of semi-naturally kept sows and piglets (except suckling) during 10 days posipartum Applied Animal Behaviour Science 31 $211-217$

Sugimoto Y, Yamasaki A, Segi E ef al. (1997) Failure of parturition in mice lacking the prostaglandin $F$ receptor Science $277681-683$

Summerlee AJS and Robertson GF (1995) Central administration of porcine relaxin stimulates drinking behaviour in rats: an effect mediated by central angiotensin II Endocrinology Journa/ 3 337-381

Summerlee AJS, Ramsey DG and Poterski RS (1998) Neutralization of relaxin within the brain affects the timing of birth in rats Endocrinology $139479-484$

Taverne MAM, Naaktgeboron C, Elsaesser F, Forsling ML, van der Weyden CC, Ellendorff $F$ and Smidt $D$ (1979) Myometrial electrical activity and plasma concentrations of progesterone, oestrogens and oxytocin during late pregnancy and parturition in the miniature pig Biology of Reproduction 21 1125-1134

Taverne $M$, Bevers M, Bradshaw JMC, Dieleman SI, Willemse AH and Porter DG (1982) Plasma concentrations of prolaclin, progesterone, relaxin and oestradiol $17 \beta$ in sows treated with progesterone, bromocriptine or indomethacin during late pregnancy Journal of Reproduction and Fertility 65 85-96

Uzumcu M, Braileanu GT, Carnation KG, Ludwig TE and Mirando MA (1998) Oxytocin stimulated phosphoinositide hydrolysis and prostaglandin $F_{2 a}$ secretion by luminal epithelial glandular epithelial and stromal celts from pig endometrium. I. Response of cyclic pigs on day 16 post-oestrus Biology of Reproduction 59 1259-1265

van der Steen HAM, Schaeffer LR, de Jong $H$ and de Groot PN (1988) Aggressive behavior of sows at parturition journal of Animal Science 66 271-279 van leengoed E, Kerker E and Swanson HH (1987) Inhibition of post-partum maternal behaviour in the rat by injecting an oxytocin antagonist into the cerebral ventricles Journal of Endocrinology 112 275-282

Varley MA and Stedman RC (1993) The influence of the early life environment on personality development and reproduction in multiparous sows Proceedings of the British Society for Animal Production 56422 (Abstract 14)

Walton SL, Burne THJ and Gilbert Cl. (2001) $\mathrm{PGF}_{2 \alpha^{-}}$ induced nesting behaviour increases hypothalamic $c$-fos and c-jun mRNA expression Proceedings of the British Neuroscience Association 16116 (Abstract)

Wang M.W, Crombie DL, Hayes IS and Heap RB (1995) Aberrant maternal behaviour in mice treated with a progesterone receptor antagonist during pregnancy Journal of Endocrinology 143 371-377

Watts AD, Flint APF, Foxcroft GR and Porter DG (1988) Plasma steroid, relaxin and dihydro-keto-prostaglandin F2alpha changes in the minipig in relation to myometrial electrical and mechanical activity in the pre-partum period journal of Reproduction and Fertility 83 553-564

Weary DM, Pajor EA, Fraser D and Honkanen A-M (1996) Sow body movements that crush piglets: a comparison between two types of farrowing accommodation Applied Animal Behaviour Science 49 149-158

Wechsler B and Hegglin D (1997) Individual differences in the behaviour of sows at the nest-site and the crushing of piglets Applied Animal Behaviour Science $5139-49$

Whitely JL, Hartmann PE, Willcox DL, Bryant-Greenwood GD and Greenwood FC (1990) Initiation of parturition and lactation in the sow: effects of delaying parturition with medroxyprogesterone acetate journal of Endocrinology 124 475-484

Widowski TM, Curtis SE, Dziuk Pl, Wagner WC and Sherwood OD (1990) Behavioral and endocrine responses of sows to prostaglandin $F_{2 \alpha}$ and cloprostenol Biology of Reproduction 43 290-297 